\title{
Improvement in antioxidant activities and cholesterol secretion inhibition abilities of black raspberry extracts upon maturation
}

\author{
Kyu Seo Chae ${ }^{1}$, Su Jung Lee ${ }^{1}$, Sung Woong Gim ${ }^{1}$, Sung Wook Cho ${ }^{1}$, \\ Ji Wung Kwon ${ }^{1 *}$, Yong-Suk Kim ${ }^{2 *}$ \\ ${ }^{1}$ Berry \& Biofood Research Institute, Gochang 56417, Korea \\ ${ }^{2}$ Department of Food Science and Technology, Jeonbuk National University, Jeonju 54896, Korea
}

\section{성숙시기별 블랙라즈베리 추출물의 항산화 활성 및 콜레스테롤 개선 효과}

$$
\begin{gathered}
\text { 채규서 }{ }^{1} \cdot \text { 이수정 }{ }^{1} \cdot \text { 김성 웅 }^{1} \cdot \text { 조성욱 }^{1} \cdot \text { 권지 웅 }^{1 *} \cdot \text { 김용성릭바바이오식품연구소, }^{2}{ }^{2} \text { 전북대학교 식품공학과 }
\end{gathered}
$$

\begin{abstract}
This study was camied out to investigate the improvements in antioxidant activities and cholesterol secretion inhibiting abilities upon the maturation of black raspberry (Rubus occidentalis, collected from May to June) for determining the suitability of black raspberry extracts for use as functional food materials. During the maturation process, the black raspberry samples were extracted by water using the reflux extraction method. The antioxidant activities of the resulting water extracts were determined in terms of the reducing power and ferric reducing antioxidant power (FRAP) and it was found that these values were higher for the unripe black raspbery sample. The cholesterol secretion inhibition activities of the extracts were then examined in $\mathrm{HepH2}$ cell, while the hydroxymethylglutaryl-coenzyme A (HMG-CoA) reductase activity and cell viability were measured in HepG2 cell. In addition, cholesterol secretion was inhibited of unripe black raspbenry in HepG2 cell. Furthermore, HMG-CoA reductase activity of the unripe black raspberry extract was found to be superior to those of the other extracts. These results, therefore, indicated that the antioxidant activity and cholesterol secretion inhibiting ability of black raspberry were reduced during maturation and thus the water extract of unripe black raspberry could be suitable for application in functional foods and medicial materials.
\end{abstract}

Key words : black raspberry, antioxidant activities, cholesterol, maturation

서 론

현대사회는 급속한 산업화에 따라 생활의 편리함을 누 리게 되었으나, 이에 따른 운동 부족 및 가공식품 등 지방 함량이 높은 식품의 섭취 위주로 식습관이 변화됨에 따라 고혈압, 동맥경화 등 혈액순환기계 질환 발병율이 증가하 고 있다(Moon, 1996; NSOK, 2003; Song 등, 2008; Kim
등, 2013). 혈액순환기계 질환의 원인은 고혈압, 비만과 함께 고지혈증을 들 수 있으며, 그중에서도 콜레스테롤의 농도가 주요한 위험인자로 보고되고 있고(NIH, 1985), 혈중 콜레스테롤의 수치가 증가될수록 뇌졸중과 심근경색으로 인한 사망률은 크게 증가하는 것으로 알려져 있다(Ebrahim 등, 2006; Tyrovolas와 Panaqiotakos, 2009).

콜레스테롤 생합성 과정에서 hydroxy-methylglutaryl

*Corresponding author. Ji Wung Kwon. E-mail : kjwung@daum.net, Phone :+82-10-8644-9104, Fax :+82-63-563-6680

Yong-Suk Kim. E-mail : kimys08@jbnu.ac.kr, Phone :+82-10-3345-4725, Fax : +82-63-270-2572

Received 16 March 2020; Revised 16 April 2020; Accepted 16 April 2020.

Copyright (C) The Korean Society of Food Preservation.

This is an Open Access article distributed under the terms of the Creative Commons Attribution Non-Commercial License (http://creativecommons.org/licenses/by-nc/4.0) which permits unrestricted non-commercial use, distribution, and reproduction in any medium, provided the original work is properly cited. 
(HMG)-CoA reductase는 콜레스테롤의 합성속도를 조절 하는 효소로 HMG-CoA reductase 활성이 저하되면 간의 LDL-receptor의 활성이 증가되어 혈중 콜레스테롤 농도를 감소시킨다(Qureshi 등, 1983; Sirtory, 1990). 이에 다양한 천연소재의 HMG-CoA reductase 억제 활성 검증을 통한 콜레스테롤 개선 연구가 많이 진행되고 있다(Oh 등, 2008; Lee 등, 2011). 또한, 고콜레스테롤 상태에서는 산화적 스 트레스(oxidative stress)를 촉진하여 생체 내 자유라디칼의 방어체계에 불균형을 가져오게 되어 심혈관계 질환을 유 발하는데 중요한 요인으로 보고되고 있다(Naito 등, 2002; $\mathrm{Wu}$ 등, 2010). 일반적으로 혈중 콜레스테롤 수치는 식이지 방의 종류와 양, 열량, 섬유소 등과 같은 식이요법을 통한 예방 및 개선이 가능하고(Balasubramaniam 등, 1985), statins, fibrates, zetia, xenical 등의 약물을 사용하기도 하지만, 이들 은 고요산혈증, 설사, 메스꺼움, 중증 근육 손상, 위장 자 극, 피부 건조, 간 기능 이상 등의 부작용(Brown, 1996)으 로 인해, 천연자원으로부터 심혈관계 질환에 도움이 되는 기능성 식품을 개발하는 연구가 지속적으로 진행되고 있 다(Oh 등, 2008; Lee 등, 2011).

복분자(Rubus occidentalis)는 장미과의 낙엽성 관목으로 국내에서 재배되는 대부분 외래종 black raspberry로 북미 가 원산지이다(Choung과 Lim, 2012). 식용으로 사용되는 복분자는 다양한 폴리페놀을 함유하고 있어 항산화, 항염 증, 항암 효과가 있다고 알려져 있으며(Jeong 등, 2010), 혈중지질개선(Choi 등, 2014), 전립선(Lee 등, 2014) 등에도 효과가 있는 것으로 보고되고 있다. 이처럼 복분자에 대한 기능성 연구는 다양하게 이루어지고 있고, 미성숙 열매와 완숙 열매에 대한 비교 연구는 이루어져 있으나, 복분자 열매가 성숙되어지는 과정에서의 항산화 활성 및 콜레스 테롤 개선 연구에 관한 연구는 이루어지지 않고 있다.

이에 본 연구에서는 다양한 기능성이 알려져 있는 복분 자 열매를 성숙되는 시기별로 채취하여 추출물을 제조하 였고, 이 추출물의 항산화 활성 및 콜레스테롤 개선 효과 를 조사하여 복분자 열매의 성숙시기가 항산화 활성 및 콜레스테롤 개선에 미치는 영향을 확인하고자 하였다.

\section{재료 및 방법}

\section{실험 재료}

본 실험에 사용된 복분자는 전라북도 고창군 흥덕면 농가에서 2018년 5월에서 6월 사이에 채취한 것으로 개화 후 $15,22,25,28,32,38,41$ 일 경과된 열매를 수확하여 22 일 이전 수확된 열매를 미숙과, 25 일부터 35 일까지의 열매를 중숙과, 그 이후부터 완숙과로 분류하였다. 수확된 열매는 $-40^{\circ} \mathrm{C}$ 에서 냉동 보관하여 실험에 사용하였다.

\section{추출물 제조}

항산화 활성 및 콜레스테롤 개선 효과를 측정하기 위한 추출물 제조는 Kwon 등(2011)의 방법을 응용하였다. 즉, 성숙시기별 복분자 열매를 $60^{\circ} \mathrm{C}$ 에서 3 일 건조한 각각의 시료 $100 \mathrm{~g}$ 에 증류수 $1,000 \mathrm{~mL}$ 를 가한 다음 $100^{\circ} \mathrm{C}$ 에서 2시간씩 2회 환류 추출을 하였다. 추출액을 여과지 (Whatman No.2, Whatman International Ltd., Maidstone, England)로 여과하고 얻은 여액을 감압농축기(R210, Buchi, Flawil, Switzerland)를 이용하여 농축 후 동결건조하여 $-70^{\circ} \mathrm{C}$ deep freezer(CLN-71UWM, Nihon freezer, Tokyo, Japan)에 서 보관하여 시료로 사용하였다.

\section{환원력(Reducing power) 측정}

복분자 성숙시기별 물 추출물의 환원력은 Oyaizu(1986) 의 방법을 이용하여 측정하였다. $100,200,300,400,500$ $\mu \mathrm{g} / \mathrm{mL}$ 농도별로 조제한 추출물 $0.1 \mathrm{~mL}$ 에 $0.2 \mathrm{M}$ sodium phosphate buffer(pH 6.6$) \quad 0.25 \mathrm{~mL}$ 및 $1 \%$ potassium ferricyanide $0.25 \mathrm{~mL}$ 를 첨가하고, $50^{\circ} \mathrm{C}$ 항온수조에서 20 분 반응시킨 후 $10 \%$ trichloroacetic acid $0.25 \mathrm{~mL}$ 를 가하였다. 그 후 $0.1 \%$ iron chloride(III) $0.05 \mathrm{~mL}$ 를 첨가하여 ELISA reader(Synergy HT, Biotec, Washington DC, USA)를 사용하 여 $700 \mathrm{~nm}$ 에서 흡광도를 측정하였다.

\section{Ferric reducing antioxidant power(FRAP) 측정}

복분자 성숙시기별 물 추출물의 $\mathrm{FRAP}$ 는 $\operatorname{Blois}(1958)$ 의 방법을 응용하여 측정하였다. 즉, $0.3 \mathrm{M}$ sodium acetate $(\mathrm{pH}$ 3.6), $10 \mathrm{mM} \mathrm{2,4,6-tris(2-pyridyl)-s-triazine(TPTZ)(Sigma-}$ Aldrich Co., St. Louis, MO, USA) 및 $20 \mathrm{mM} \mathrm{FeCl}_{3} \cdot 6 \mathrm{H}_{2} \mathrm{O}$ 를 제조하여 실험 직전에 10:1:1의 비율로 혼합하여 FRAP 용액을 제조하였다. FRAP 용액 $0.75 \mathrm{~mL}$ 와 농도별(100, $200,300,400,500 \mu \mathrm{g} / \mathrm{mL}$ )로 제조된 시료 $0.03 \mathrm{~mL}$ 씩 첨가 한 후 $37^{\circ} \mathrm{C}$ 항온수조에서 15 분간 반응 후 ELISA reader (Synergy HT, Biotec, Washington DC, USA)를 사용하여 $593 \mathrm{~nm}$ 에서 흡광도를 측정하였다.

\section{세포주 및 세포 배양}

실험에 사용된 HepG2 cell은 American Type Culture Collection(ATCC, Manassas, VA, USA)에서 구입하였다. 세포 배양을 위해 Eagle's Minimum Essential Medium (EMEM, Corning Incorporated, Corning, NY, USA)에 fetal bovine serum(FBS, welgene, Seoul, Korea) 10\%, antibioticantimycotic/Thermo fisher scientific. Waltham. MA, USA) $1 \%$ 가 함유되게 첨가하여 $95 \%$ 습도, $5 \% \mathrm{CO}_{2}, 37^{\circ} \mathrm{C}$ 세포 배양기(INC108med $\mathrm{CO}_{2}$ incubator, Memmert $\mathrm{GmbH}+\mathrm{Co}$. $\mathrm{KG}$, Schwabach, Germany)에서 배양하였다. 


\section{콜레스테롤 생성 억제효과 분석}

복분자 성숙시기별 물 추출물의 세포내 콜레스테롤 생 성에 미치는 영향을 확인하기 위해 HepG2 cell을 6-well culture plate에 $3 \times 10^{5}$ cells/well로 분주하여 24시간 배양 후, 복분자 성숙시기별 물 추출물을 24 시간 처리하였다. 이후 세포 배양액을 제거한 뒤 phosphate-buffered saline (PBS)로 각 well을 세척한 뒤 cholesterol/cholesterol ester quantitation kit(BioVision, Milpitas, CA, USA)에서 제공된 분석법에 따라 세포 내 콜레스테롤의 양을 측정하였다 (Lee 등, 2014).

\section{HMG-CoA reductase 활성 억제효과 분석}

복분자 성숙시기별 물 추출물이 HMG-CoA reductase activity에 미치는 영향을 확인하기 위해 HMG-CoA reductase activity kit(Sigma-Aldrich Co.)를 이용하여 측정하였다(Lee 등, 2014).

\section{세포 생존율(Cell viability assay)}

복분자 성숙시기별 물 추출물의 세포독성실험을 위해 HepG2 cell을 96-well culture plate에 $2 \times 10^{4}$ cells/well의 농도 로 분주를 하고 24 시간 동안 안정화를 시킨 후, 복분자 성숙 단계별 물 추출물을 $0,15.63,31.25,62.50,125,250,500$, $1,000 \mu \mathrm{g} / \mathrm{mL}$ 의 농도로 24 시간 동안 처리하였다. 이후 cell viability assay kit(EZ-cytox, Dogen, Seoul, Korea)에서 제 공 하는 방법을 토대로 ELISA reader(Synergy HT, Biotec)를 사용하여 $450 \mathrm{~nm}$ 에서 흡광도를 측정하였다.

\section{통계처리}

본 연구의 각 시험항목별 실험결과는 3 회 반복 분석하여, SPSS program 23.0(Statistical Package for Social Sciences, SPSS Inc., Chicago, IL, USA)을 이용하여 통계처리 후 평 균 및 표준편차로 나타내었다. 각 시험군 간의 통계적 유 의성 검증은 Duncan의 다중범위검정(Duncan's multiple range test)으로 실시하였으며, 유의성은 $\mathrm{p}<0.05$ 수준에서 검증하였다.

\section{결과 및 고찰}

\section{추출물 수율}

추출물의 수율과 생리활성 효과가 항상 비례하지는 않 으며, 시료의 특성 및 추출조건에 따라 수율과 생리활성 물질 함량은 달라질 수 있다. 또한, 추출물의 수율은 생리 활성이 우수하여도 수율이 낮을 경우 경제성이 떨어지기 때문에 추출 수율은 산업화를 위한 상업적 이용가치를 판단하는 중요한 요인이다(Ham 등, 2015). 성숙시기별 복 분자 열매의 항산화 활성 및 콜레스테롤 개선 효과를 검증
하기 위하여 제조한 물 추출물의 수율을 측정한 결과는 Table 1과 같다. 복분자 열매의 경우, 성숙시기에 따라 추 출수율의 차이가 크게 나타났는데, 개화 후 15 일 열매의 추출 수율은 $27.40 \pm 0.40 \%$ 로 시간이 지남에 따라 점차 감 소하는 경향을 보이다 중숙과로 분류되는 개화 후 28 일부 터 수율이 다시 증가하여 완숙 열매가 되는 개화 후 41 일 열매의 추출 수율은 $49.17 \pm 1.05 \%$ 로 미성숙 열매보다 약 $1.7-2.5$ 배 이상 높은 수율을 보였다.

\section{환원력}

항산화 활성을 측정하는 방법에는 여러 가지가 있으나, 환원력은 $700 \mathrm{~nm}$ 에서 ferric-ferricyanide $\left(\mathrm{Fe}^{2+}\right)$ 혼합물이 수소 를 공여하여 유리라디칼을 안정화시킴으로써 ferrous $\left(\mathrm{Fe}^{2+}\right)$ 로 전환하는 환원력을 흡광도로 나타낸 것이다(Sa 등, 2010).

성숙시기별 복분자 물 추출물의 농도별 환원력을 측정 한 결과(Fig. 1), 농도 의존적으로 활성이 증가하는 경향을 보였는데, 특히 미성숙 시기의 열매에서 환원력이 높은 것을 확인하였다. $500 \mu \mathrm{g} / \mathrm{mL}$ 동일 농도에서 환원력을 비 교한 결과, 각각 $0.524 \pm 0.030,0.504 \pm 0.010,0.524 \pm 0.005$, $0.432 \pm 0.007,0.344 \pm 0.006,0.246 \pm 0.003,0.207 \pm 0.002,0.206 \pm$ $0.002,0.167 \pm 0.010$ 으로 성숙시기가 증가할수록 환원력의 활성이 낮아지는 것으로 나타났다. 환원력은 $\mathrm{DPPH}$ 및 $\mathrm{ABTS}$ 라디칼 소거활성과 밀접한 관계를 가지고 있는 것 으로 보고(Choi 등, 2007)되어, 본 실험에서 환원력이 가장 높았던 복분자 미숙과의 항산화 활성이 가장 높은 것으로 나타났다.

\section{FRAP}

성숙시기별 복분자 물 추출물의 산화 및 환원 반응을

Table 1. Extraction yield of black raspberry during maturation

\begin{tabular}{cl}
\hline Days after fruit set (Date) & Yield $(\%)$ \\
\hline $15\left(\right.$ May $\left.23^{\text {rd }}\right)$ & $27.40 \pm 0.40^{1) \mathrm{e} 2)}$ \\
$18\left(\right.$ May $\left.26^{\text {th }}\right)$ & $23.87 \pm 0.61^{\mathrm{f}}$ \\
$22\left(\right.$ May $\left.30^{\text {th }}\right)$ & $22.07 \pm 1.70^{\mathrm{fg}}$ \\
$25\left(\right.$ June $\left.2^{\text {th }}\right)$ & $18.47 \pm 0.42^{\mathrm{h}}$ \\
$28\left(\right.$ June $\left.5^{\text {th }}\right)$ & $20.89 \pm 0.92^{\mathrm{g}}$ \\
$32\left(\right.$ June $\left.9^{\text {th }}\right)$ & $31.95 \pm 1.48^{\mathrm{d}}$ \\
$35\left(\right.$ June $\left.13^{\text {th }}\right)$ & $41.16 \pm 1.20^{\mathrm{c}}$ \\
$38\left(\right.$ June $\left.16^{\text {th }}\right)$ & $44.40 \pm 1.11^{\mathrm{b}}$ \\
41 (June $\left.19^{\text {th }}\right)$ & $49.17 \pm 1.05^{\mathrm{a}}$ \\
\hline
\end{tabular}

${ }^{1)}$ Value are mean \pm SD

2)a-h Indicate statistically significant differences of black raspberry during maturation $(\mathrm{p}<0.05)$. 


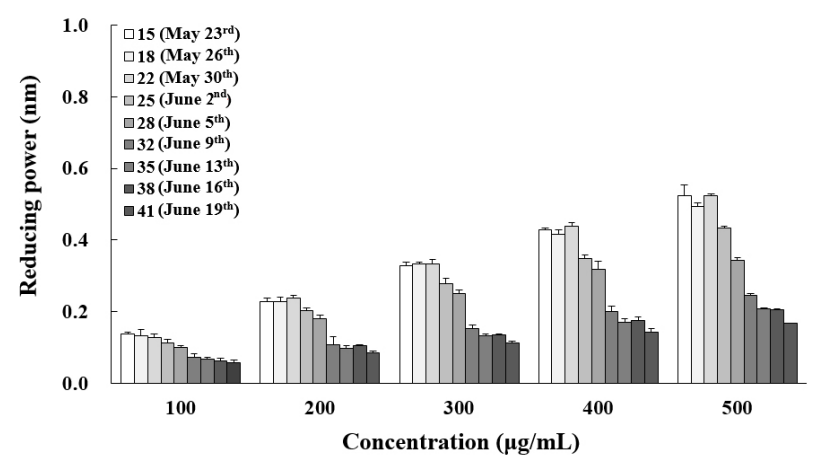

Fig. 1. Reducing power of black raspberry during maturation.

이용한 항산화 활성을 측정하기 위하여 $\mathrm{FRAP}$ 를 측정한 결과는 Fig. 2와 같다. 성숙시기별 모든 추출물이 농도 의 존적으로 FRAP 활성이 증가하였고, 환원력과 마찬가지로 미성숙 시기의 추출물이 가장 높은 활성을 나타내었다. 특히 개화 후 18 일차 열매의 물 추출물이 가장 높은 활성을 보였는데, $100,200,300,400,500 \mu \mathrm{g} / \mathrm{mL}$ 농도에서 각각 $0.364 \pm 0.010, \quad 0.503 \pm 0.022, \quad 0.675 \pm 0.010, \quad 0.735 \pm 0.012$, $0.869 \pm 0.049$ 로 나타나 가장 낮은 활성을 보인 개화 후 41 일 차 열매보다 $500 \mu \mathrm{g} / \mathrm{mL}$ 농도에서 비교할 경우 약 1.9 배 이상 높은 활성을 보여, 성숙시기에 따라 과실은 항산화 물질의 함량 및 활성에 차이를 보인다는 연구보고(Choi 등, 2009)와 같았다. 복분자 열매의 경우, 미성숙 시기에서 FRAP 활성이 가장 높은 것을 확인하였고, 중간숙과부터 활성이 점차 떨어져 완숙 시기에서 활성이 가장 낮게 나타 났다. Cha 등(2007)의 성숙단계별로 복분자딸기의 항산화 활성 측정을 위해 DPPH 라디칼 소거활성을 측정한 결과, 복분자 완숙과가 중숙과 및 미숙과보다 높은 활성을 보였 다는 결과와는 다른 결과를 보였는데, 이는 시료의 추출조 건 및 품종의 차이와 항산화 활성을 측정하기 위한 실험방 법에 차이로 판단된다. 그러나 Kwon 등(2011)은 복분자 미숙과 및 완숙과 열매의 항산화 활성을 측정한 결과에서

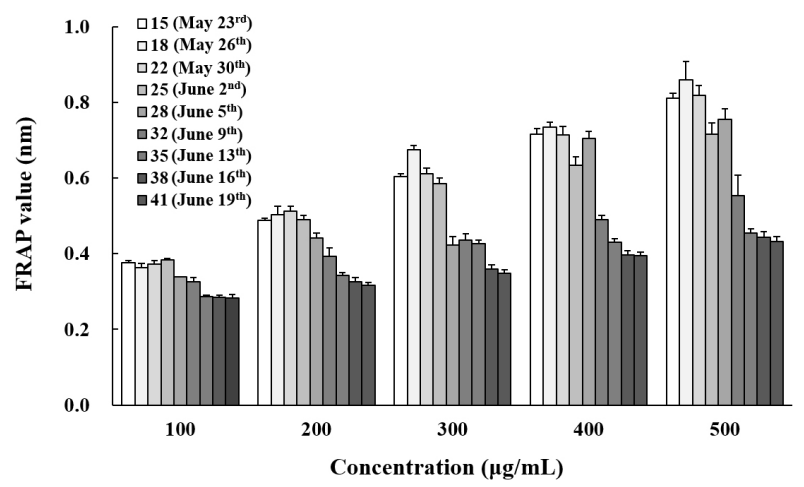

Fig. 2. FRAP of black raspberry during maturation.
는 완숙과보다 미숙과 열매에서 항산화 활성이 우수하다 고 보고하여 본 실험과 같은 결과를 보였다.

결과적으로 복분자 열매의 경우, 성숙시기와 관계없이 모두 항산화 활성을 보였으며, 특히 복분자 미성숙 열매가 높은 항산화 활성을 보여 항산화 기능성 식품 소재로 복분 자 열매를 활용하고자 할 때 미성숙 열매를 사용하는 것이 좋을 것으로 판단된다.

\section{콜레스테롤 개선 효과}

콜레스테롤의 체내 생합성은 간에서 이루어진다. 콜레 스테롤 합성의 시작은 acetyl group을 가진 acetyl $\mathrm{CoA} 3$ 개 분자가 결합하여 (acetyl CoA에서 1개 + acetoacetyl CoA에 서 2개) $\mathrm{HMG}-\mathrm{CoA}$ 가 생성된다(Cerqueira 등, 2016). 본 연 구에서는 복분자 성숙시기별 물 추출물이 세포내 콜레스 테롤 생성에 어떠한 영향을 미치는지를 확인하기 위해 각 추출물을 $\mathrm{HepG} 2$ 세포에 처리한 뒤 세포내 합성된 콜레 스테롤의 양을 측정하였다(Fig. 3). 그 결과, 그룹 간 다소 차이를 보였으나, 복분자의 성숙시기의 모든 그룹에서 세 포내 콜레스테롤의 생성이 억제되었다. 콜레스테롤 생성 에 가장 큰 억제 효능을 보인 그룹은 개화 후 15 일 차 열매로써, 정상대조군에 비해 $50 \%$ 감소되었고, 개화 후 22 일 차 열매의 경우 $47 \%$, 그리고 개화 후 $18,25,35$ 일 차 열매의 경우 약 $39 \%$ 의 콜레스테롤 감소를 나타내었다. 이러한 결과는 Lee 등(2014)의 복분자 미성숙 열매와 완숙 열매 추출물에서의 콜레스테롤 생성 억제 효능에 관한 비교 연구에서 복분자 미성숙과 추출물에서 콜레스테롤 억제 효능을 보인 결과와 동일한 결과는 나타내었다. 따라 서 성숙시기별 복분자 물 추출물의 세포내 콜레스테롤 생성 억제 효능 결과를 통해 개화 후 15 일 차 열매가 콜레

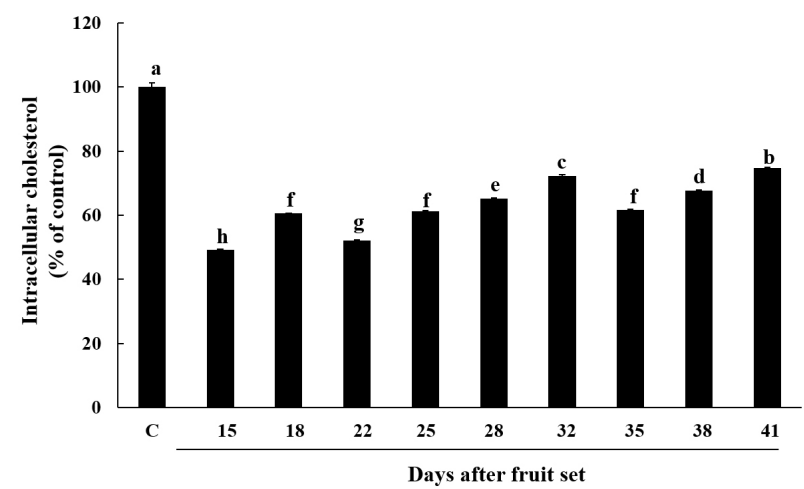

Fig. 3. Effect of intracellular cholesterol synthesis inhibition by extracts of black raspberry during maturation in HepG2 cells.

Intracellular cholesterol was measured in cell lysates from HepG2 cells incubated with the indicated $200 \mu \mathrm{g} / \mathrm{mL}$ concentrations of extracts of black raspberry during maturation. Data indicates significant difference by Duncan's multiple range tests $(\mathrm{p}<0.05, \mathrm{n}=3)$.

C, control. 
스테롤 개선에 가장 효과가 높은 것으로 나타났다.

\section{HMG-CoA reductase 저해 활성}

HMG-CoA reductase는 콜레스테롤을 합성하는 전 과정 에서 속도를 결정하는(rate-controlling step) 단계로서 콜레 스테롤의 합성량을 조절하는 데에 큰 영향력을 갖는다 (Russell과 DeBose, 2008). 고콜레스테롤 및 동맥경화 치료 에 널리 쓰이고 있는 statin 계열의 약물은 HMG-CoA reductase의 활성을 억제를 통해 많은 부작용이 보고되었 다. 따라서 이러한 부작용 없이 HMG-CoA reductase의 활 성을 억제시킬 수 있는 bioactive compound에 관한 연구들 이 다수 진행되어왔다(Agarwal과 Rao, 1988; Auger 등, 2005; Loke 등, 2010).

복분자 성숙시기별 물 추출물이 $\mathrm{HepG} 2$ 세포에서 콜레 스테롤 생성 억제 결과를 바탕으로 HMG-CoA reductase 활 성에 어떠한 영향을 미치는지 확인하였다(Fig. 4). 대조군으 로 사용된 pravastatin $(50 \mathrm{nM})$ 을 기준으로 복분자 성숙시기 별 물 추출물의 HMG-CoA reductade 억제 활성을 확인한 결과, 성숙시기가 이른 개화 후 $15,18,22,25,28$ 일 차 열매를 각각 처리한 그룹에서 억제 활성을 나타내었다. 그중에서도 특히 개화 후 22 일 차 열매 처리 그룹은 유의 미한 HMG-CoA reductade 억제 활성을 나타내었으며, 이 는 세포내 콜레스테롤 억제 결과에서도 동일한 효과를 나타내었다. 이러한 원인으로 복분자 미성숙 시기 열매에 함유된 phytochemical의 약리 작용에 의한 것으로 판단된 다. 특히 복분자 미성숙 열매에는 ellagic acid, gallic acid, ferulic acid, caffeic acid 등의 phenolic 화합물이 다량 함유 되어 있다(Shin 등, 2018). 그리고 베리류에 다량 포함되어 있는 ellagic acid는 특히 복분자 열매의 주요 지표성분으로

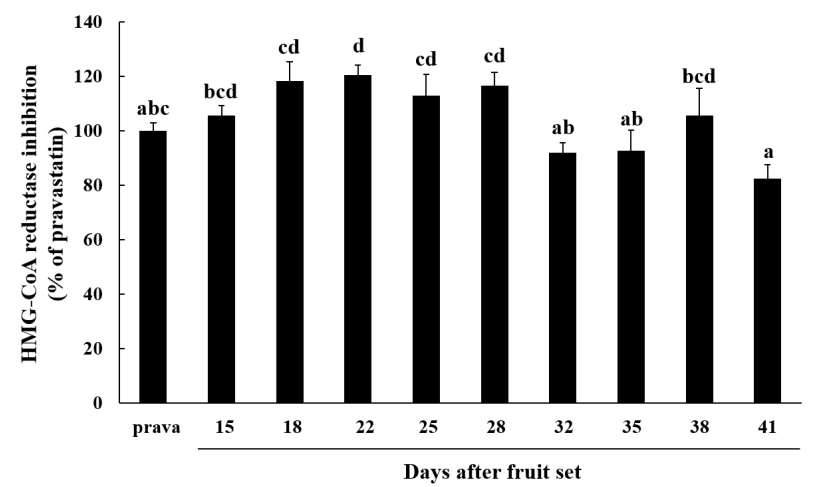

Fig. 4. Effect of extracts of black raspberry during maturation on HMG-CoA reductase activity.

HMG-CoA reductase activity was measured treated with $200 \mu \mathrm{g} / \mathrm{mL}$ concentrations of extracts of black raspberry. Each value represents the mean and SE. Graph indicates significant difference by Duncan's multiple range tests $(\mathrm{p}<0.05, \mathrm{n}=3)$.

Prava, pravastatin $(50 \mathrm{nM})$.
써 고콜레스테롤로 인한 동맥경화 예방에 효과가 있다는 연구 내용이 발표된 바 있으며(Park 등, 2011), gallic acid (Ngamukote 등, 2011)와 ferulic acid(Myoung 등, 2010)의 콜레스테롤 억제에 관한 다수 연구들이 발표된 바 있다. Salvamani 등(2014)은 동맥경화에 효과를 나타내는 식물 성 flavonoid들에 관한 연구를 진행하였고, quercetin, kaempferol, myricetin, rutin, naringenin 등이 콜레스테롤 저하 를 통해 동맥경화에 효과는 나타낸다고 보고하였다. 본 연구에서 진행된 복분자 성숙시기별 물 추출물의 세포내 콜레스테롤 생합성 억제와 HMG-CoA reductase 억제 활성 에 관한 연구를 종합해 볼 때 복분자에 열매에 포함되어 있는 polyphenol 및 flavonoid, anthocyanin들로 인해 콜레 스테롤 억제 효과를 나타내는 것으로 판단된다.

\section{세포 생존율(Cell viability assay)}

$\mathrm{HepG} 2$ 세포에 복분자 성숙시기별 물 추출물을 24시간 농도별로 처리하여 세포생존율을 확인한 결과는 Fig. 5와 같다. 성숙시기별 물 추출물은 $250 \mu \mathrm{g} / \mathrm{mL}$ 의 농도에서 $80 \%$ 생존율을 보였으며, 그 이상의 농도인 $500 \mu \mathrm{g} / \mathrm{mL}$ 의 농도 에서는 일부의 경우 생존율이 감소하는 경향을 보였다. 특히 수확시기가 이른 15 일 차부터 25 일 차의 경우, 생존율 이 $80 \%$ 미만으로 감소하는 반면, 수확시기가 늦어질수록 생존율이 $90 \%$ 로 나타났다. 이러한 결과는 $\mathrm{Kim}$ 등(2004)의 생육시기별 피자두 추출물의 암세포 증식 억제 효과에 관한 연구 결과와 동일한 결과를 확인하였다. Kim 등 (2004)의 연구 결과에서는 미성숙 시기의 피자두 에탄올 추출물이 인간유래 암세포(6종)의 생존율을 현저히 억제 되었다고 보고하였다. 따라서 수확시기가 이른 미성숙 시 기의 복분자 열매에 비해 수확시기가 늦은 완숙과 열매가 세포에 대한 독성이 덜 한 것으로 판단된다.

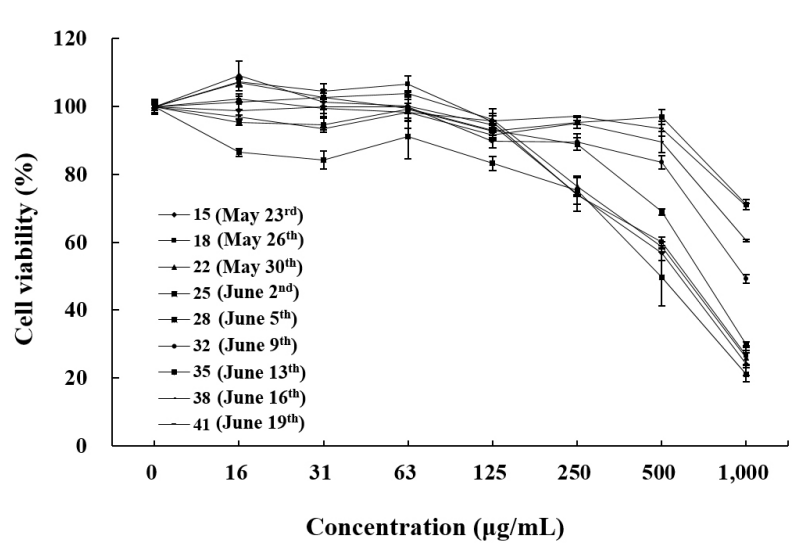

Fig. 5. Percentages of cell viability of HepG2 cells treated for 24 $h$ with black raspberry during maturation relative to that of untreated controls, evaluated with the MTS assay $(n=3)$. 


\section{요 약}

본 연구에서는 항산화 활성 및 콜레스테롤 개선에 효과 가 있는 것으로 알려진 복분자 열매를 성숙시기별로 수확 하여 물 추출물을 제조하고, 이에 대한 항산화 활성 및 콜레스테롤 개선 효과 검증을 위해 콜레스테롤 생성억제, HMG-CoA reductase 저해 활성을 측정하였다. 성숙시기별 복분자 열매의 추출 수율을 확인한 결과, 미숙과 열매보다 중숙과 열매에서 수율이 낮은 것으로 나타났고, 이후 완숙 과로 분류되는 시기부터 추출 수율이 증가하는 것으로 나타났다. 항산화 활성 측정을 위해 환원력을 측정한 결과, 미성숙 시기에서 가장 높은 환원력을 보였고, 열매가 성숙 됨에 따라 환원력은 낮아지는 것으로 나타났다. 또한, FRAP를 측정한 결과에서도 환원력과 마찬가지로 미성숙 열매에서 가장 높은 활성을 보였고, 중숙과, 완숙과 순으로 높은 활성을 보였다. 콜레스테롤 개선 효과를 검증한 결과 에서는 콜레스테롤 합성에 관여하는 HMG-CoA reductase 활성은 미성숙 시기의 열매에서 높게 나타났고, 간세포주 (HepG2 cells) 내 콜레스테롤 억제 결과에서도 미성숙 시기 에서 동일하게 높은 효과를 보였다. $\operatorname{Kim}(2005)$ 의 뽕나무 품종별, 시기별 뽕잎과 오디의 항산화능 분석 연구에서 미성숙 열매에서 항산화 활성이 높았다는 연구보고와 같 은 경향을 보였고, Lee 등(2014)의 복분자 미성숙 열매가 완숙 열매보다 높은 콜레스테롤 억제 효능을 보였다는 연구와 동일한 결과를 보였다.

이러한 결과를 종합해볼 때 복분자 열매는 성숙시기와 상관없이 항산화 활성 및 콜레스테롤 개선에 효과를 보였 으며, 미성숙 시기에서 높은 활성을 보이는 것으로 나타났 다. 특히 개화 후 15 일 차 열매가 항산화 활성 및 콜레스테 롤 개선 효과에 모두 높은 수준의 활성을 보이며 추출 수율도 높게 나타나, 항산화 활성 및 콜레스테롤 개선에 효과가 있는 복합 기능성 소재로써 복분자 열매를 산업화 하고자 할 때 개화 후 15 일 차 열매를 활용하는 것이 좋을 것으로 판단된다.

\section{감사의 글}

본 연구는 농림축산식품부가 지원하는 2015년 농촌자 원복합산업화지원사업 향토건강식품명품화사업에 의해 수행된 연구결과이며, 연구비 지원에 감사드립니다.

\section{Conflict of interests}

The authors declare no potential conflict of interest.

\section{ORCID}

Kyu Seo Chae https://orcid.org/0000-0002-7228-4626

Ji Wung Kwon https://orcid.org/0000-0002-2832-4811

Yong-Suk Kim https://orcid.org/0000-0003-1331-4175

\section{References}

Agarwal S, Rao AV. Tomato lycopene and low density lipoprotein oxidation: a human dietary intervention study. Lipids, 33, 981-984 (1998)

Auger C, Teissedre PL, Gerain P, Lequeux N, Bornet A, Serisier S, Besancon P, Caporiccio B, Cristol JP, Rouanet JM. Dietary wine phenolics catechin, quercetin and resveratrol efficiently protect hypercholesterolemic hamsters against aortic fatty streak accumulation. J Agric Food Chem, 53, 2015-2021 (2005)

Balasubramaniam S, Simons LA, Chang S, Hickie JB. Reduction in plasma cholesterol and increase in biliary cholesterol by a diet rich in n-3 fatty acids in the rat. J Lipid Res, 26, 684-689 (1985)

Blois MS. Antioxidant determinations by the use of a stable free radical. Nature, 181, 1199-1200 (1958)

Brown SL. Lowered serum cholesterol and low mood. BMJ, 313, 637-638 (1996)

Cerqueira NMFSA, Oliveira EF, Gesto DS, Santos-Martins D, Moreira C, Moorthy HN, Ramos MJ, Fernandes PA. Cholesterol biosynthesis: A mechanistic overview. Biochemistry, 55, 5483-5506 (2016)

Cha HS, Youn AR, Park PJ, Choi HR, Kim BS. Comparison of physiological activities of Rubus coreanus Miquel during maturation. J Korean Soc Food Sci Nutr, 36, 683-688 (2007)

Choi HR, Lee JH, Lee SJ, Lee MJ, Jeong JT, Lee TB. Effects of unripe black raspberry water extract on lipid metabolism and oxidative stress in mice. Korean J Food Sci Technol, 46, 489-497 (2014)

Choi SR, You DH, Kim JY, Park CB, Kim DH, Ryu J. Antioxidant activity of ethanol extracts from Cudrania tricuspidata Bureau according to harvesting parts and time. Korean J Medicinal Crop Sci, 17, 115-120 (2009)

Choi YM, Jeong HS, Lee JS. Antioxidant activity of methanolic extracts from some grains consumed in Korea. Food Chem, 103, 130-138 (2007)

Choung MG, Lim JD. Antioxidant, anticancer and immune activation of anthocyanin fraction from Rubus coreanus 
Miquel fruit (Bokbunja). Korean J Med Crop Sci, 20, 259-269 (2012)

DeBose-Boyd RA. Feedback regulation of cholesterol synthesis: Sterol-accelerated ubiquitination and degradation of HMG CoA reductase. Cell Res, 18, 609-621 (2008)

Ebrahim S, Sung JH, Song YM, Ferrer RL, Lawlor DA, Smith GD. Serum cholesterol, haemorrhagic stroke, ischaemic stroke, and myocardial infarction: Korean national health system prospective cohort study. BMJ, 333, 22-27 (2006)

Ham HM, Woo ks, Lee BW, Park JY, Sim EY, Kim BJ, Lee CW, Kim SJ, Kim WH, Lee JS, Lee YY. Antioxidant compounds and activities of methanolic extracts from oat cultivars. J Korean Soc Food Sci Nutr, 44, 1660-1665 (2015)

Jeong JH, Jung H, Lee SR, Lee HJ, Hwang KT, Kim TY. Antioxidant, anti-proliferative and anti-inflammatory activities of the extracts from black raspberry fruits and wine. Food Chem, 123, 338-344 (2010)

Kim HB. Anti-oxidative capacity analysis of water-soluble substances according to varieties and maturity stages in mulberry leaves and fruits. Korean J Seric Sci, 47, 62-67 (2005)

Kim HJ, Yu MH, Lee SO, Park JH, Park DC, Lee IS. Effects of plum fruits extracts at different growth stages on quinone reductase induction and growth inhibition on cancer cells. J Korean Soc Food Sci Nutr, 33, 1445-1450 (2004)

Kim MS, Chun SS, Choi JH. Effects of turmeric (Curcuma longa L.) on antioxidative systems and oxidative damage in rats fed a high fat and cholesterol diet. J Korean Soc Food Sci Nutr, 42, 570-576 (2013)

Kwon JW, Lee HK, Park HJ, Kwon TO, Choi HR, Song JY. Screening of biological activities to different ethanol extracts of Rubus coreanus Miq.. Korean J Medicinal Crop Sci, 19, 325-333 (2011)

Lee HS, Yang ST, Ryu BH. Effects of aged black garlic extract on lipid improvement in rats fed with high fat-cholesterol diet. J Life Sci, 21, 884-892 (2011)

Lee MJ, Lee SJ, Choi HR, Lee JH, Kwon JW, Chae KS, Jeong JT, Lee TB. Improvement of cholesterol and blood pressure in fruit, leaf and stem extracts from black raspberry in vitro. Korean J Medicinal Crop Sci, 22, 177-187 (2014)

Lee SJ, Choi HR, Lee JH, Kwon JW, Lee HK, Jeong JT, Lee TB. Effects of unripe black raspberry extracts on prostate cancer cell line and rat model of benign prostatic hyperplasia. J Korean Soc Food Sci Nutr, 43, 507-515 (2014)

Loke WM, Proudfoot JM, Hodgson JM, Mckinly AJ, Hime N, Magat M, Stoker R, Croft KD. Specific dietary polyphenols attenuate atherosclerosis in apolipoprotein e-knockout mice by alleviating inflammation and endothelial dysfunction. Arterioscler Thromb Vasc Biol, 30, 749-757 (2010)

Moon SJ. Nutrition problems of Korean. J Nutr Health, 29, 371-380 (1996)

Naito M, Wu X, Nomura H, Kodama M, Kato Y, Osawa $\mathrm{T}$. The protective effects of tetrahydrocurcumin on oxidative stress in cholesterol-fed rabbits. J Atheroscler Thromb, 9, 243-250 (2002)

National Institutes of Health (NIH). Lowering blood cholesterol to prevent heart disease. J Am Med Assoc, 253, 2080-2086 (1985)

Ngamukote S, Makynen K, Thilawech T, Adisakwattana S. Cholesterol-lowering activity of the major polyphenols in grape seed. Molecules, 16, 5054-5061 (2011)

National Statistical Office Korea (NSOK). Annual Report of the Cause of Death Statistics. Natl Stat Office Korea, Seoul, Korea (2003)

Oh S, Hong SS, Kim YH, Koh SC. Screening of biological activities in fern plants native to Jeju Island. Korean J Plant Res, 21, 12-18 (2008)

Oyaizu M. Studies on products of browning reactionantioxidative activities of products of browning reaction prepared from glucosamine. Japan J Nutr Diet, 44, 307-315 (1986)

Park SH, Kim JL, Lee ES, Han SY, Gong JH, Kang MK, Kang YH. Dietary ellagic acid attenuates oxidized LDL uptake and stimulates cholesterol efflux in murine macrophages. J Nutr, 141, 1931-1937 (2011)

Qureshi AA, Abuirmeileh N, Din ZZ, Elson CE, Burger WC. Inhibition of cholesterol and fatty acid biosynthesis in liver enzymes and chicken hepatocytes by polar fractions of garlic. Lipids, 18, 343-348 (1983)

Sa YJ, Kim JS, Kim MO, Jeong HJ, Yu CY, Park DS, Kim MJ. Comparative study electron donating ability, reducing power, antimicrobial activity and inhibition of $\alpha$-glucosidase by Sorghum bicolor extracts. Korean J Food Sci Technol, 42, 598-604 (2010)

Salvamani S, Gunasekaran B, Shaharuddin NA, Ahmad SA, Shukor MY. Antiartherosclerotic effects of plant flavonoids. 
Biomed Res Int, Article ID: 480258 (2014)

Shin D, Chae KS, Choi HR, Lee SJ, Gim SW, Kwon GT, Lee HT, Song YC, Kim KJ, Kong HS, Kwon JW. Bioactive and pharmacokinetic characteristics of prematured black raspberry, Rubus occidentalis. Ital J Food Sci, 30, 428-439 (2018)

Sirtory CR. Pharmacology and mechanism of action of the new HMG-CoA reductase inhibitors. Pharmcol Res, 22, 555-563 (1990)

Son MJ, Rico CW, Nam SH, Kang MY. Influence of oryzanol and ferulic acid on the lipid metabolism and antioxidative status in high fat-fed mice. J Clin Biochem Nutr, 46, 150-156 (2010)

Song YB, Kyung JS, Park SB, Wee JJ, Do JH, Kim YS. Influence of Korean red ginseng water extract on recovery of hepatic function in hypercholesterolemic mice fed cholesterol diet. J Ginseng Res, 32, 283-290 (2008)

Tyrovolas S, Panagiotakos DB. The role of Mediterranean type of diet on the development of cancer and cardiovascular disease, in the elderly: A systematic review. Maturitas, 65, 122-130 (2010) 